[0000-0003-1506-9759] [0000-0003-2445-6259]

В. С. Моркун, д.m.н., професор,

І. А. Котов, к.т.н., доиент,

Криворізький національний університет

вул. Віталія Матусевича, 11, м. Кривий Ріг, Україна, 50027

e-mail: rioexito@gmail.com

\title{
КРИТЕРІЇ ОПЕРАТИВНОГО МОНІТОРИНГУ БАЗИ ПРОФЕСІЙНИХ КОНЦЕПТІВ КОМПЛЕКСУ АВТОМАТИЗАЦІЇ КЕРУВАННЯ ЕНЕРГОСИСТЕМИ
}

Статтю присвячено проблемі розробки критерїв оперативного моніторингу й оцінювання ефективності інтелектуальної системи підтримки рімень для протиаварійного керування режсимами енергосистем на основі використання професійних концептів і спеціалізованих тезаурусів. Запропоновано критерії розрахунку оперативності використання професійних кониептів тезауруса знань про автоматизацію ліквідації аварій в енергосистемі.

Наукова новизна полягає в розробиі та застосуванні коефіцієнтів ефективності тезауруса професійної лексики, що трунтуються на поданні професійних конщептів знань про ліквідацію аварій в енергосистемі. Отримані показники дають можливість оиінювати ступінь професійності й ефективності лінгвістичного корпусу і будувати продуктивні бази знань. На відміну від існуючих підходів до побудови баз знань, запропонований підхід дає змогу уніфікувати проектування систем підтримки прийняття рімень та скоротити час їх реалізації.

Практичне значення одержсаних результатів полягає в очінюванні ефективності використання професійних знань для побудови уніфікованих інтелектуальних систем підтримки рішень в галузі протиаварійного керування енергосистемами. Результати роботи полягають у забезпеченні оперативного моніторингу ефективності використання бази знань професійних концептів термінів і сленгу. Запропонована модель оцінювання ефективності професійного тезауруса базується на відношенні інтенсивностей зростання загального та спеціалізованого професійного тезаурусів.

Результати досліджень доводять зростання ефективності професійних тезаурусів при переході до більш специфічних спеціалізованих науково-технічних галузей.

Ключові слова: диспетчерське керування, онтологія, тезаурус, колокачія, семантика, абревіатура.

Вступ. При розгляді аварійних ситуацій у складних промислових системах необхідно завжди враховувати так званий «людський фактор», який відіграє значну роль у виникненні та формуванні збитків. Керуючий персонал відчуває великий психофізіологічний тиск і не завжди може адекватно реагувати на аварійну ситуацію [1-3].

Сучасна енергосистема (ЕС) є великим комплексним ієрархічним об'єктом керування, що характеризується одночасністю процесів вироблення, розподілу і споживання енергії. У зв'язку з цим особливої актуальності набуває комп'ютерна інтелектуальна підтримка прийняття рішень оперативного диспетчерського персоналу (ОДП). Системи підтримки прийняття рішень (СППР) інтегруються в оперативні інформаційно-керуючі комплекси (ОІКК) автоматизованої системи диспетчерського керування (АСДК) енергосистеми SCADA [4].

Продуктивність СППР значною мірою обумовлена ефективністю використання професійного тезауруса. Тому $є$ актуальною проблема дослідження і розробки критеріїв оперативного моніторингу ефективності використання бази концептів професійної лексики в СППР для протиаварійного керування режимами енергосистем. 3 огляду на специфіку професійної галузі, як одну з форм подання знань було обрано форму фактуальних колокацій, а як джерело професійної лексики лінгвістичний корпус ліквідації аварій та запобігання їм в енергосистемі [5].

Аналіз останніх джерел досліджень і публікацій. Багато вітчизняних і зарубіжних вчених накопичили значний досвід в галузі розробки теоретичних моделей і практичної реалізації форм подання баз знань (БЗ). Відзначимо деяких із них: Башликов А. А., Вагін В. М., Венделін А. Г., Геловані В. А., Евланова Л. Г., Кретов В. С., Ларічев О. І., Лю-

(C) В. С. Моркун, I. А. Котов, 2021

DOI: $10.24025 / 2306-4412.1 .2021 .230075$ 
барський Ю. Я., Лорьер Ж. Л., Люггер Дж. Ф., Поспєлов Д. А., Самойлов В. Д., Таунсенд К., Терелянський П. В., Ульман Дж., Уотермен Д., Фішберн П. К., Форсайт Ф., Чаплинський Ю. П.

В галузі інтелектуалізації управління режимами ЕС варто зазначити роботи Баркалова С. А., Баркан Я. Д., Бартоломея П. І., Башликова А. А., Бердникова Р. Н., Буткевича А. Ф., Глазунової А. М., Гришанова С. О., Любарського Ю. Я., Місріханова М. Ш., Панасецького Д. А., Поспєлова Г. Є., Чебана В. М. та інших [6-12].

Однією з головних задач при побудові та впровадженні СППР є розробка адаптивної моделі подання професійної лексики $[13,14]$. Як уніфікована модель подання професійних знань може служити апарат онтологій [15]. Платформою побудови онтологій є професійний тезаурус.

Згідно 3 [16-18] оцінювання оперативної ефективності проводиться на основі декількох підходів. Їх можна розділити на дві групи: 1) група методів оцінювання економічної ефективності і 2) група методів оцінювання оперативної (технічної) ефективності [19].

На основі аналізу можна зробити висновок про відсутність єдиних уніфікованих рішень в галузі подання професійних знань і оцінювання ефективності баз професійних тезаурусів концептів. Проведений аналіз досліджень і публікацій підтверджує актуальність проблеми розробки критеріїв оперативного моніторингу бази професійних концептів.

Мета та задачі дослідження. Метою дослідження $\epsilon$ розробка критеріїв оперативного моніторингу використання бази професійних концептів комплексу автоматизації керування енергосистеми. На основі розроблених критеріїв можна показати, що використання специфічних професійних тезаурусів $є$ ефективним для скорочення обсягів БЗ і підвищення швидкості роботи СППР.

Відповідно до мети дослідження поставлено такі завдання:

- розробити формально-логічну модель онтології фактуальних колокацій;

- побудувати БЗ на основі підмножини лінгвістичного корпусу ліквідації аварій та запобігання їм в енергосистемі;

- побудувати загальний тезаурус професійної лексики;

- побудувати спеціалізований тезаурус професійних термінів і сленгу;
- провести статистичну обробку вихідної лексичної вибірки та професійних тезаурусів;

- розробити критерії оперативного моніторингу застосування тезауруса фактуальних колокацій професійного лінгвістичного корпусу ліквідації аварій в енергосистемі;

- показати практичну цінність і значимість розроблених моделей і критеріїв оцінювання ефективності бази професійних концептів.

Постановка розрахункових експериментів та отримання результатів дослідження. Узагальнюючи висновки 3 [18], приймемо, що під оперативною ефективністю інтелектуальної системи можна розуміти ефективність обробки структур знань в БЗ, різноманітність методів, спрощення та скорочення часу процедур доступу до знань, що, в кінцевому підсумку, забезпечує підвищення гнучкості і швидкості обробки знань. Таким чином, оперативна ефективність обумовлюється двома факторами - ефективністю подання Б3 і ефективністю обробки структур знань у БЗ. Причому, основним фактором, що впливає на загальну оперативну ефективність СППР, $є$ оперативна ефективність подання БЗ. 3 цієї точки зору, зробимо оцінювання оперативної ефективності Б3, побудованої на інкорпорації професійних онтологій.

Багаторівнева інкорпорація форм знань, представлених на базі єдиного підходу еволюції тезаурусів, забезпечує високу оперативну ефективність використання БЗ. Головним фактором $є$ єдиний механізм обробки знань усіх онтологічних рівнів.

Тому розглянемо задачу оцінювання ефективності тезауруса концептів і тезауруса фактуальних колокацій професійного лінгвістичного корпусу ліквідації аварій в енергосистемі. При розгляді вищих рівнів ієрархії Б3 оперативний ефект використання розробленої еволюції онтологій буде тільки наростати. Для вирішення цього завдання можна застосувати розроблені математичні моделі професійного тезауруса фактуальних колокацій. Розробимо критерії оцінювання його ефективності в рамках моделі онтології. На основі розроблених критеріїв можна показати, що використання специфічних професійних тезаурусів $\epsilon$ ефективним для скорочення обсягів БЗ і підвищення швидкості роботи СППР.

Як правило колокації структури елементарного факту приймемо, що елементарний 
факт - це триплет атомарних висловлювань (лексем спеціалізованого тезауруса), що розглядається як ізольований орграф. При інтерпретації фактів кожен із елементів триплета розглядається як одна лінгвістична константа або значення лінгвістичної змінної. Як основу для репрезентації фактів використовують формальні моделі атомарних висловлювань, які утворюють активний тезаурус і не мають зв'язків між собою. Для колокації фактів утворюються трійки пов'язаних атомарних висловлювань як атомарних лексем триплетів фактів.

Специфіка професійної галузі - управління режимами енергосистем - полягає в глибокій структурованості та ієрархічності лінгвістичних блоків і концептів. Як вихідний експертний лінгвістичний корпус використовуємо інструктивний диспетчерський матеріал: «12. Дії оперативного персоналу при втраті власних потреб на ПС» [20]. У зазначеній професійній галузі зробимо вибірку елементарних концептів. Введемо множини висловлювань, які умовно відносяться до одного контексту $c_{0}$. Короткий фрагментарний приклад тезауруса наведено нижче: $S_{1}^{C 0}=$ «відключення»; $S_{2}^{C 0}=$ «робочий трансформатор»; $\quad S_{2}{ }^{C 0}=$ «власні потреби»; $S_{3}{ }^{C 0}=$ «відновлення напруги»; $S_{4}{ }^{C 0}=$ «секція»; $S_{5}{ }^{C 0}=$ «в результаті дії АВР»; $S_{6}{ }^{C 0}=\ll 0,4$ кВ»; $S_{7}{ }^{C 0}=$ «черговий персонал»; $S_{8}{ }^{C 0}=$ «включити резервний трансформатор»; $S_{9}{ }^{C 0}=$ «подати напругу»; $\quad S_{10}{ }^{C 0}=$ «вступний $\quad$ автомат»; $S_{11}{ }^{C 0}=$ «секційний вимикач»; $S_{12}{ }^{C 0}=$ «відновлення напруги»; $S_{13}{ }^{C 0}=$ «по блінкеру визначити»; $S_{14}{ }^{C O}=$ «відключився трансформатор»; $S_{15}{ }^{C 0}=$ «вимірювання опору ізоляції».

Подібним чином побудована структурно-лінгвістична модель уніфікованої професійної онтології елементарних фактів. Факти формувалися на основі усталених лінгвістичних форм професійної галузі. На основі отриманих колокацій побудований загальний тезаурус лексичного корпусу.

В свою чергу, на основі загального тезауруса виділено тезаурус спеціальних професійних термінів і сленгу. Обсяг цього фрагмента фактуальної бази знань - 63 факти.

На основі фактичних даних наведемо графічну інтерпретацію вибірки концептів тезауруса по наростаючій, яка показана на рисунку 1.

3 рисунка 1 видно, що зростання обсягу лексем фактуальної Б3 значно випереджає зростання тезауруса. Цей ефект значною мі- рою обумовлений професійною специфікою проблемної галузі та масовим використанням у текстах специфічного сталого сленгу.

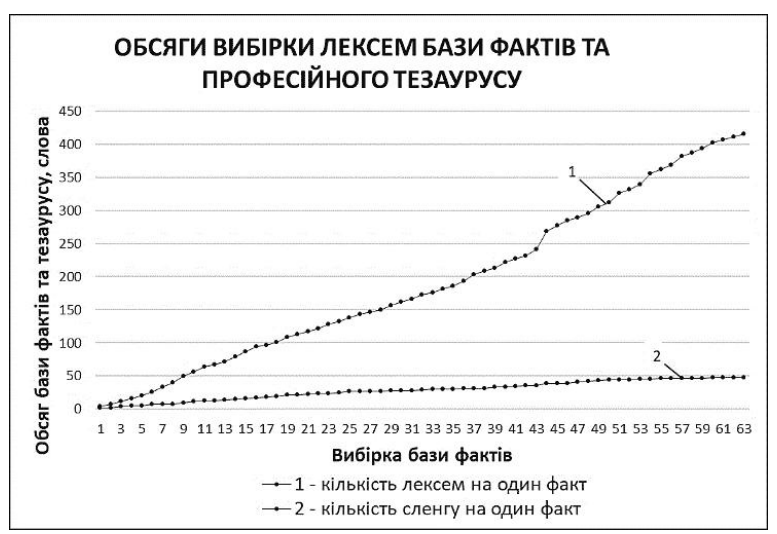

Рисунок 1 - Динаміка вибірки лексем і тезауруса Б3 по наростаючій

При побудові автоматизованих систем обробки професійних текстів і в Б3 інтелектуальних систем більший інтерес становлять виміри вибірки в деяких кодах, символах чи байтах. На рисунку 2 показано результати абсолютної вибірки в символах (буквах) по наростаючій фактів БЗ загального і спеціального професійного тезаурусів.

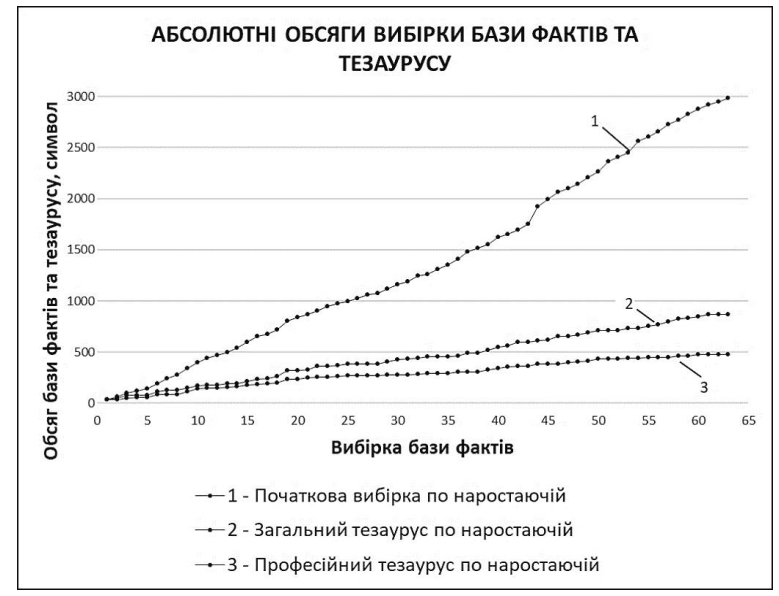

Рисунок 2 - Динаміка абсолютної вибірки БЗ і тезаурусів по наростаючій

Рисунок 2 свідчить, що специфічний професійний тезаурус сленгу й абревіатур має ще меншу інтенсивність зростання, що свідчить про його підвищену ефективність та необхідність використання. Виходячи з отриманих даних, в роботі було запропоновано показник оцінювання ступеня професійності БЗ $\left(D_{p}\right)$

$$
D_{p}=\frac{N_{F W T A}^{+}}{N_{F W}^{+}} 100 \%,
$$


де $N_{F W T A}^{+}$- кількість лексем сленгу й абревіатур по наростаючій, слів; $N_{F W}^{+}-$загальна кількість лексем по наростаючій, слів.

Особливістю цього показника $є$ врахування структури фактів і специфіки семантичного навантаження кожного 3 трьох концептів факту. На рисунку 3 показано динаміку зміни показника ступеня професійності БЗ.

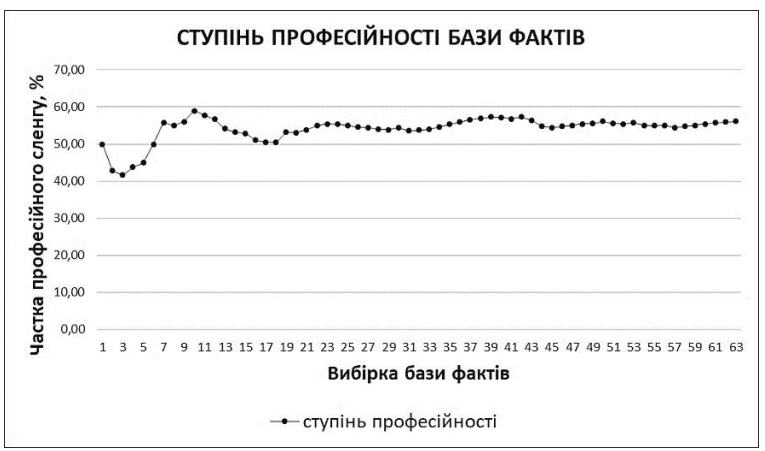

Рисунок 3 - Показник ступеня професійності Б3 по наростаючій

Як видно, показник $D_{p}$ швидко стабілізується щодо середнього значення. Показник характеризує вміст у структурованих формах представлення знань специфічної професійної лексики i сленгу. Інтерпретація графіка на рисунку 3 полягає в тому, що у специфічній лексиці інструктивних матеріалів по ліквідації аварій і запобіганню їм в енергосистемах, структурованій у формі фактів, відсоток специфічного сленгу й абревіатур становить понад $55 \%$.

У роботі пропонується кілька варіантів показників ефективності тезаурусів. Перший показник оцінює абсолютну ефективність, виражену кількісно в символах (або байтах), як надмірність, ліквідовану використанням загального $\left(E_{F T}^{a b s}\right)$ або спеціального $\left(E_{F T A}^{a b s}\right)$ тезаурусів

$$
\begin{aligned}
& E_{F T}^{a b s}=\Delta V_{F-F T}=V_{F}^{+}-V_{F T}^{+}, \\
& E_{F T A}^{a b s}=\Delta V_{F-F T A}=V_{F}^{+}-V_{F T A}^{+},
\end{aligned}
$$

де $V_{F}^{+}-$обсяг фактів по наростаючій, символ; $V_{F T}^{+}-$обсяг загального тезауруса фактів по наростаючій, символ; $V_{F T A}^{+}-$обсяг тезауруса сленгу й абревіатур по наростаючій, символ.

Абсолютні величини ефективності тезаурусів показують стійке зростання надмірності лінгвістичного корпусу по відношенню до словників. Ілюстрація абсолютної ефективності тезаурусів наведена на рисунку 4.

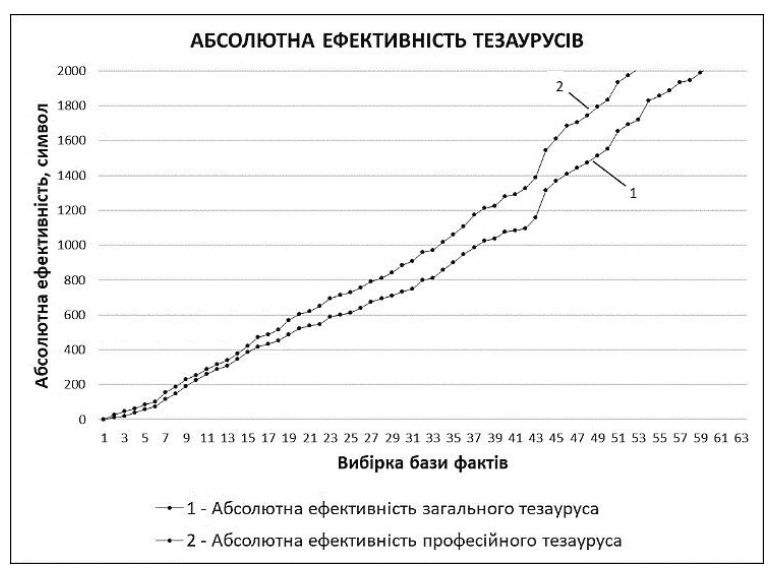

Рисунок 4 - Динаміка зростання абсолютної ефективності тезаурусів

Однак тезауруси також зростають в обсягах. Тому становить інтерес відношення абсолютної ефективності до обсягу бази фактів по наростаючій. 3 цією метою в роботі запропоновано другий показник ефективності тезаурусів - показник відносної ефективності загального $\left(E_{F T}^{r e l}\right)$ або спеціального $\left(E_{F T A}^{r e l}\right)$ тезаурусів

$$
\begin{aligned}
& E_{F T}^{r e l}=\frac{E_{F T}^{a b s}}{V_{F}^{+}} 100 \%=\frac{V_{F}^{+}-V_{F T}^{+}}{V_{F}^{+}} 100 \%, \\
& E_{F T A}^{r e l}=\frac{E_{F T A}^{a b s}}{V_{F}^{+}} 100 \%=\frac{V_{F}^{+}-V_{F T A}^{+}}{V_{F}^{+}} 100 \% .
\end{aligned}
$$

Всі компоненти формул (3) аналогічні компонентам формул (2).

Ілюстрація динаміки відносної ефективності тезаурусів наведена на рисунку 5.

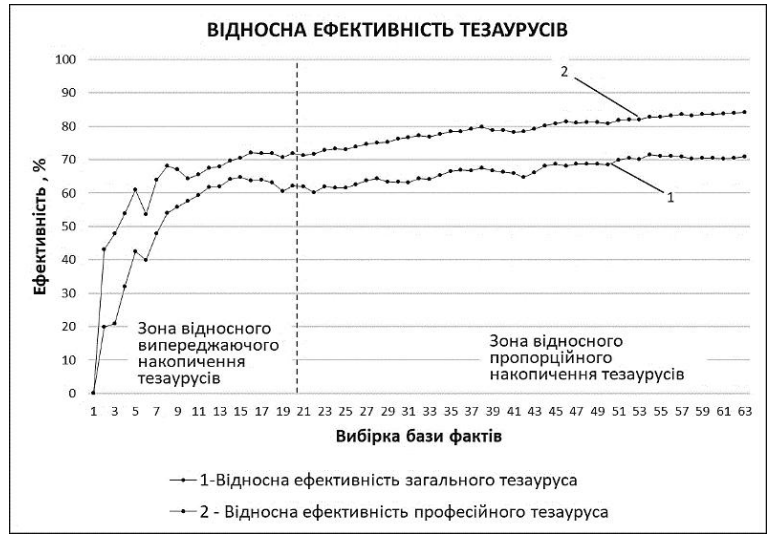

Рисунок 5 - Динаміка зростання відносної ефективності тезаурусів

Як видно, графіки мають дві явно виражені зони - зону відносного випереджаючого накопичення тезаурусів і зону відносного про- 
порційного зростання тезаурусів. Причому, ефективність спеціального тезауруса абревіатур і сленгу вища ефективності загального тезауруса. Зона відносного випереджаючого накопичення тезаурусів характеризується накопиченням бази фактів в єдиному термінологічному і семантичному блоці, коли тезаурус формується швидко і практично не зростає. Зона відносного пропорційного зростання тезаурусів характерна для збільшення обсягу лінгвістичного корпусу, коли накопичуються нові термінологічні та семантичні блоки. При цьому тезаурус знову починає зростати в обсязі.

Показники відносної ефективності професійних тезаурусів $є$ інформативними і адекватно відображають семантичний і кількісний характер бази фактів лінгвістичного корпусу ліквідації аварій в енергосистемі. Однак ці показники змінюються при накопиченні БЗ і при об'єднанні кількох специфічних галузей. Тому виникає необхідність у стійкому інтегральному показнику ефективності тезаурусів. 3 цією метою в роботі запропоновано третій показник - інтегральний коефіцієнт ефективності тезаурусів. Його розрахунок грунтується на апроксимації показників абсолютної ефективності тезаурусів.

Графічні результати апроксимації і пояснення до розрахунків наведені на рисунку 6 .

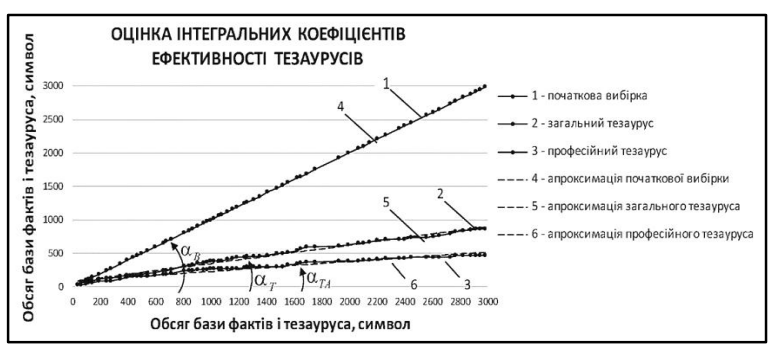

Рисунок 6 - Розрахунок інтегральних коефіціснтів ефективності тезаурусів

Фізичний сенс інтегрального коефіцієнта ефективності тезауруса полягає у відношенні кута нахилу апроксимуючої прямої швидкості зростання тезауруса до кута нахилу апроксимуючої прямої швидкості зростання вихідної бази. Оскільки обсяги вибірки дані по осях в однакових одиницях і масштабах, то кути нахилів апроксимуючих прямих будуть стабілізуватися.

Вирази для розрахунків інтегральних коефіцієнтів ефективності тезауруса, відповідно, загальної та професійної абревіатур і сленгу наведені у вигляді наступних формул:

(C) В. С. Моркун, I. А. Котов, 2021 DOI: $10.24025 / 2306-4412.1 .2021 .230075$

$$
\begin{gathered}
K_{E T}=\left(1-\frac{\alpha_{T}}{\alpha_{B}}\right) 100 \%=\left(1-\frac{\operatorname{arctg}\left(a_{T}\right)}{\operatorname{arctg}\left(a_{B}\right)}\right) 100 \%, \\
K_{E T A}=\left(1-\frac{\alpha_{T A}}{\alpha_{B}}\right) 100 \%=\left(1-\frac{\operatorname{arctg}\left(a_{T A}\right)}{\operatorname{arctg}\left(a_{B}\right)}\right) 100 \%,(5)
\end{gathered}
$$

де $K_{E T}$ - коефіцієнт ефективності загального тезауруса; $K_{E T A}$ - коефіцієнт ефективності тезауруса абревіатур і сленгу; $\alpha_{T}-$ кут нахилу апроксимуючої прямої для загального тезауруса; $\alpha_{T A}-$ кут нахилу апроксимуючої прямої для тезауруса абревіатур і сленгу; $\alpha_{B}-$ кут нахилу апроксимуючої прямої для бази фактів; $a_{T}$ - коефіцієнт при $V_{K B}$ У рівнянні прямої для загального тезауруса; $a_{T A}-$ коефіцієнт при $V_{K B}$ у рівнянні прямої для тезауруса абревіатур і сленгу; $a_{B}$ - коефіцієнт при $V_{K B}$ у рівнянні прямої для бази фактів.

Підстановка розрахункових значень дає наступні результати:

$$
\begin{gathered}
K_{E T}=\left(1-\frac{\operatorname{arctg}(0.2751)}{\operatorname{arctg}\left(a_{1}\right)}\right) 100 \%=65.82 \%, \\
K_{E T A}=\left(1-\frac{\operatorname{arctg}(0.1439)}{\operatorname{arctg}(1)}\right) 100 \%=81.81 \%,
\end{gathered}
$$

Таким чином, ефективність загального тезауруса становить $65,82 \%$, а ефективність тезауруса абревіатур і сленгу $-81,81 \%$. Отже, оперативна ефективність використання бази знань, побудованої на інкорпорації професійних онтологій, буде тим вищою, чим більш спеціалізованою буде професійна галузь СППР. Професійна галузь протиаварійного керування режимами енергосистем $\epsilon$ вузькоспеціалізованою і тому побудова для неї спеціалізованих тезаурусів є доцільною.

Оцінимо практичний вплив підвищення оперативної ефективності багаторівневої онтологічної БЗ на ефективність роботи ОДП. Для цієї мети проведено програмну апробацію методики на фактичних даних оперативного управління нештатною ситуацією електричної мережі енергосистеми. Використано інструктивні і практичні дані диспетчерських тренувань. Розглянуто аварійне управління перетіканням потужності в перетині Південноукраїнська AEC - Вінниця. Напрямок перетікання - на Захід. В рамках єдиної БЗ побудовано онтології концептів, фактів, продукцій.

Програмний комплекс контролює перетікання по перетину для поточного стану схеми мережі. При виході значення за нормовані межі система генерує величини керуючих 
впливів на основі матриць чутливості. Потім використовуються продукції з бази правил для формування рад диспетчеру у напрямку дій, ступеня регулювання режиму або зміни схеми енергосистеми.

Отримане технічне рішення застосоване до тестових протиаварійних тренувань (ПАТ) диспетчерського персоналу. Як об'єкт управління використано розрахункові режимні моделі електричної мережі ОЕС України. Було оброблено результати тренування двох однакових груп диспетчерського персоналу з однаковими кваліфікацією та досвідом роботи: 1-а група (зміна - 2 людини) без використання СППР; 2-а група (зміна - 2 людини) з використанням СППР в оперативному режимі.

Згідно 3 протоколом тренувань оцінювання дій диспетчерів здійснювалося групою експертів за 5-бальною системою відповідно до методики, запропонованої в [21].

Вихідні умови тренування:

- контрольований об'єкт - перетин ПУАЕС - Вінниця. Перетин включає такі лінії: ПЛ-750 кВ ПУАЕС - Вінниця, ВЛ-330 кВ Конотоп - Ніжин. ВЛ-330 кВ КремГЕС - Черкаси, ВЛ-330 кВ ПУАЕС - Побужжя, ВЛ330 кВ Трихати - Аджалик, ВЛ-330 кВ Гомель - Чернігів, ВЛ-330 кВ Мозир - ЧАЕС;

- схема роботи мережі - нормальна;

- режим роботи 3 ОЕС країн Східної Європи - паралельний;

- величина перетікання по ВЛ 750 кВ

ПУАЕС - Вінниця - 1300 МВт;

- допустиме перетікання в перерізі для

заданих умов - 3600 МВт;

- зафіксоване перетікання по міжсистемному транзиту (перетину) - 3640 МВт;

- зафіксоване перевищення міжсистемного перетікання - 40 МВт;

- зафіксована часткова відмова в роботі або недостатня ефективність дії протиаварійної автоматики (ПА);

- відбулося порушення синхронної роботи ОЕС України і ОЕС країн Східної Свропи.

Завдання тренування - згідно з інструкцією ліквідувати перевищення міжсистемного перетікання протягом 1-2 хв. В іншому випадку диспетчер енергосистеми зобов'язаний розділити несинхронно працюючі частини енергосистеми.

Стратегія тренування - виконати завдання $\mathrm{i}$ зробити формування наступних оцінних параметрів діяльності диспетчерів $[21,22]: q_{1}$ - правильно, своєчасно виконані (C) В. С. Моркун, I. А. Котов, 2021 DOI: $10.24025 / 2306-4412.1 .2021 .230075$ дії; $q_{2}$ - невиконані дії; $q_{3}$ - неправильні дії; $q_{4}-$ дії, виконані з запізненням; $q_{5}$ - дії, виконані раніше необхідного; $q_{6}$ - зайві дії; $q_{7}-$ неоптимальні дії.

В ході тренування на основі бази знань і матриць чутливості СППР визначила необхідні регулюючі дії:

- загальний регулюючий вплив 12,5 МВт;

- регулюючий вплив Дністровської ГЕС - 11,36 МВт;

- регулюючий вплив Канівської ГЕС 1,14 МВт.

Після проведення незалежних протиаварійних тренувань (без використання СППР і 3 використанням СППР) і отримання параметрів $q_{1}-q_{7}$ були обчислені такі експертні професійно-психологічні характеристики диспетчерських змін: $\alpha$ - професіоналізм; $\rho$ - надійність роботи; $\beta$ - рівень підготовки; $\gamma$ - психологічна стійкість у роботі; $\delta$ - оперативність і чіткість у роботі; $\lambda$ - інтенсивність закономірних відмов диспетчерських змін; $Y-$ оцінювання умовних збитків від недовідпуску електроенергії та зниження іiі якості.

Професійні та психологічні характеристики ОДП, що обчислюються на основі протоколу дій учасника тренувань:

професіоналізм -

$$
\alpha=\frac{q_{1}}{\sum_{i=1}^{7} q_{i}} ;
$$

надійність роботи -

$$
\rho=1-\frac{\sum_{i=2}^{7} q_{i}}{\sum_{i=1}^{7} q_{i}} ;
$$

рівень підготовки -

$$
\beta=1-\frac{\sum_{i=3}^{4} q_{i}}{\sum_{i=1}^{7} q_{i}}
$$

психологічна стійкість у роботі-

$$
\gamma=1-\frac{\sum_{i=5}^{6} q_{i}}{\sum_{i=1}^{7} q_{i}}
$$


оперативність і чіткість у роботі-

$$
\delta=\frac{q_{4}+q_{7}}{\sum_{i=1}^{7} q_{i}} .
$$

Результати проведених тренувань наведено в таблиці 1. Як видно з таблиці, використання інтелектуальних засобів системи підтримки рішень позитивно і цілком визначено впливає на результати тестових протиаварійних тренувань ОДП. Показники професіоналізму, надійності, рівня підготовки, психологічної стійкості, чіткості в роботі зросли. Інтенсивність закономірних відмов знизилася.

\section{Таблиця 1 - Результати тестових протиаварійних тренувань ОДП}

\begin{tabular}{|l|l|}
\hline \multicolumn{1}{|c|}{$\begin{array}{c}\text { Показники } \\
\text { СПППР }\end{array}$} & \multicolumn{1}{c|}{$\begin{array}{c}\text { Показники } \\
\text { з використанням } \\
\text { СППР }\end{array}$} \\
\hline$q_{1}=4,80$ & $q_{1}=4,96$ \\
$q_{2}=1,00$ & $q_{2}=1,00$ \\
$q_{3}=0,50$ & $q_{3}=0,34$ \\
$q_{4}=2,20$ & $q_{4}=1,24$ \\
$q_{5}=0,20$ & $q_{5}=0,14$ \\
$q_{6}=0,20$ & $q_{6}=0,12$ \\
$q_{7}=1,80$ & $q_{7}=0,55$ \\
\hline$\alpha=4,8 / 10,7=0,4486$ & $\alpha=4,96 / 8,35=0,5940$ \\
$\rho=1-4,1 / 10,7=0,6168$ & $\rho=1-2,84 / 8,35=0,6599$ \\
$\beta=1-2,7 / 10,7=0,7477$ & $\beta=1-1,58 / 8,35=0,8108$ \\
$\gamma=1-0,4 / 10,7=0,9626$ & $\gamma=1-0,26 / 8,35=0,9689$ \\
$\delta=1-4,0 / 10,7=0,6262$ & $\delta=1-1,79 / 8,35=0,7856$ \\
\hline$\lambda=0,048$, відмов/мiс. & $\lambda=0,037$, відмов/міс. \\
\hline$Y=c_{1} P_{1} 2,8$ & $Y=c_{2} P_{2} 0,92$ \\
\hline
\end{tabular}

На основі проведених досліджень, розробки математичних моделей і практичного тестування програмного забезпечення СППР можна сформулювати такі результати дослідження:

- розроблено формально-логічну модель колокацій професійних концептів;

- побудовано базу знань на основі підмножини лінгвістичного корпусу ліквідації аварій та запобігання їм в енергосистемі;

- побудовано загальний тезаурус професійної лексики;

- побудовано спеціалізований тезаурус професійних термінів і сленгу;

- проведено статистичну обробку вихідної лексичної вибірки та професійних тезаурусів;

(C) В. С. Моркун, I. А. Котов, 2021 DOI: $10.24025 / 2306-4412.1 .2021 .230075$
- розроблено критерії оперативного моніторингу застосування тезауруса бази знань професійного лінгвістичного корпусу ліквідації аварій в енергосистемі;

- показано практичну цінність і значимість розроблених моделей і критеріїв оцінювання ефективності бази професійних концептів.

Обговорення результатів дослідження. Практична корисність отриманих результатів передбачає наступне. Обсяг тезауруса значно менший за початковий мовний корпус, тому створення, подання, сприйняття й інтерпретація фактів за допомогою тезауруса стають набагато простішими. Застосування тезауруса систематизує побудову та використання баз знань у розумних системах. Розроблений підхід дає можливість побудувати уніфіковані системи підтримки прийняття рішень для різних професійних сфер та скоротити час, необхідний для розробки систем підтримки прийняття рішень, що робить їх більш дешевими. Застосування моделі онтології до професійної галузі доцільне через специфічну структуру професійної лексики. Отримані залежності показують, що збільшений обсяг професійної лексики збільшує надмірність тексту швидше, ніж обсяг тезауруса, що пояснюється підвищеною ефективністю останнього. Очевидно, що для загального словника ефективність онтологічних моделей знизиться через необхідність використання більшого тезауруса. Ось чому моделі онтології доцільно використовувати в конкретних професійних галузях, відомих широким колом професійних термінів (професійний сленг та абревіатури). Отримані результати дослідження сприятимуть створенню онтологічних моделей для різних форм представлення знань.

Запропоновані в статті рішення спрямовані на автоматизацію оперативного моніторингу аварійних ситуацій в енергосистемах. Розроблені показники ефективності професійних тезаурусів дають змогу програмно реалізувати систему підтримки рішень для управління аварійним режимом енергосистеми. Результатом циклу роботи протиаварійної системи $є$ рекомендації на базі диспетчерських нормативно-інструктивних матеріалів, а також значення корегувальних впливів. Після розробки СППР вона може бути впроваджена в комплекс апаратно-програмних засобів діючої АСДУ енергосистеми. Переважни- 
ми точками впровадження протиаварійної СППР є блок автоматизованих робочих місць, блок технологічної мережі обміну даними, блок збору даних і телеуправління.

Висновки і перспективи подальших досліджень. Узагальнення результатів тренувань ОДП дає можливість зробити наступні висновки про доцільність і оперативну ефективність застосування інкорпорації професійних онтологій у практиці диспетчерського керування ЕЕС в аварійних ситуаціях, а саме:

- оперативні характеристики ОДП, що працює разом 3 СППР, підвищилися на $20,29 \%$;

- інтенсивність відмов диспетчерських змін скоротилася на 22,92 \%;

- умовний збиток від недовідпуску електроенергії скоротився на 67,14\%.

Таким чином, підтверджено практичний позитивний ефект застосування багаторівневої онтологічної Б3 на підвищення оперативної ефективності роботи ОДП.

Як перспективу подальших досліджень можна відзначити напрям оперативного моніторингу використання баз знань, побудованих на основі колокацій семантичних мереж і продукцій.

\section{Список використаних джерел}

[1] "Аварийность в энергосистеме Украины за год выросла вдвое", Unian.net, 2021. [Электронный ресурс]. Режим доступа: https://www.unian.net/economics/energetics /1073586-avariynost-v-energosistemeukrainyi-za-god-vyirosla-vdvoe.html.

[2] Y. Besanger, M. Eremia, and N. Voropai, "Major grid blackouts: Analysis, classification, and prevention", in Handbook of electrical power system dynamics: Modeling, stability, and control. New Jersey: Wiley, IEEE Press, 2013, pp. 789-863.

[3] С. Смоловик, "Роль "человеческого фактора" в развитии крупных системных аварий", Elektroenergetika, vol. 1, no. 1, pp. 16-19, 2008.

[4] SCADA System. Application Guide, 1st ed. Milwaukee: Allen-Bradley, Rockwell Automation, 2005, p. 420.

[5] Міністерство палива та енергетики України. Державне підприємство Національна енергетична компанія "Укренерго", "Інструкція ДС-8 щодо запобігання і лікві- дації технологічних порушень в електричній частині електростанцій і електричних мереж регіону Дніпровської ЕС", Дніпровська електроенергетична система, Запоріжжя, 2008.

[6] А. А. Башлыков, и А. П. Еремеев, Основы конструирования интеллектуальных систем поддержки принятия решений в атомной энергетике. Москва: ИНФРАM, 2017.

[7] А. М. Глазунова, и И. Н. Колосок, "Решение задач диспетчерского управления интеллектуальными электроэнергетическими системами на базе методов оценивания состояния", в Энергетика России в XXI веке. Инновачионное развитие и управление. Иркутск, 2015, с. 1-8.

[8] M. Negnevitsky, N. Tomin, D. Panasetsky, and V. Kurbatsky, "Intelligent approach for preventing large-scale emergencies in electric power systems", in IEEE Int. Conf. on Electric Power Engineering PowerTech, France, 2013, pp. 1-6.

[9] С. А. Гришанов, та Н. А. Канашевич, "Реалізація експертної системи для діагностики генераторів теплових електричних станцій", в 3б. наук. працьь X Міжнар. наук.-техн. конф. молодих вчених $і$ спеціалістів, Кременчук, 2012, с. 305-306.

[10] С. А. Баркалов, А. В. Душкин, и С. А. Колодяжный, Введение в системное проектирование интеллектуальных баз знаний. Москва: Горячая линия-Телеком, 2017.

[11] А. Н. Антамошин, О.Н. Близнова, и А. А. Большаков, Интеллектуальные системы управления организационнотехническими системами, 2-е изд. Москва: Горячая линия-Телеком, 2016.

[12] Ю. Я. Любарский, Интеллектуальные информационные системь. Москва: Наука. Гл. ред. физ.-мат. лит., 1990.

[13] А. А. Азарян, та I. А. Котов, "Структурно-логічна модель фактів як засіб репрезентації характеристик компонентів електроенергетичних систем", Гірничий вісник: наук.-техн. зб. Кривий Ріг, № 103, с. 136$141,2018$.

[14] K. Iskandar, M. Jambak, R. Kosalaa, and H. Prabowo, "Current issue on knowledge management system for future research: A systematic literature review", in 2nd Int. Conf. on Computer Science and Computa-

(C) В. С. Моркун, I. А. Котов, 2021

DOI: $10.24025 / 2306-4412.1 .2021 .230075$ 
tional Intelligence (ICCSCI) 2017, Bali, 2017, pp. 68-80.

[15] V. Morkun, and I. Kotov, "Information technologies for power supply dispatch control based on linguistic corpus ontologies", Науковий вісник Національного гірничого університету: зб. наук. пр., Дніпро: НТУ "Дніпровська політехніка", № 6 (174), c. 130-136, 2019.

[16] С. Деверадж, и Р. Кохли, "Тайны ИТ. Измерение отдачи от инвестиций в информационные технологии". Москва: БукПресс, 2006.

[17] В. Липаев, Выбор и оценивание характеристик качества программных средств: методы и стандарты. Москва: Синтег, 2001.

[18] Б. Железко, и О. Синявская, "Методы оценки эффективности интеллектуальных компонент систем поддержки принятия решений", Научные труды Белорусского государственного экономического университета: сб. / В.Н. Шимов и др. (редкол). Минск: БГЭУ, 2010, с. 139-144.

[19] А. Л. Рыжко, Н. М. Лобанова, Н. А. Рыжко, и Е. О. Кучинская, Экономика информационных систем. Москва: Финансовый ун-т, 2014.

[20] Міністерство палива та енергетики України. Державне підприємство Національна енергетична компанія "Укренерго", "Інструкція по ліквідації аварій і технологічних порушень режиму в електричних мережах BAT ЕК "Дніпрообленерго", Дніпровська електроенергетична система. Запоріжжя, 2007.

[21] А. Ф. Дьяков, И. Е. Лековец, Г. В. Меркурьев, и А. Д. Щербаков, "Оценка противоаварийных тренировок оперативнодиспетчерского персонала энергосистем", Электрические станции, т. 2, с. 58-65, 1997.

[22] Г. В. Меркурьев, Оперативно-диспетчерское управление энергосистемами. Санкт-Петербург: Центр подготовки кадров энергетики, 2002.

\section{References}

[1] "The emergency in the energy system of Ukraine has doubled in a year", Unian.net, 2021. [Online]. Available: https://www.unian.net/economics/energetics/ 1073586-avariynost-v-energosistemeukrainyi-za-god-vyirosla-vdvoe.html [in Russian].

[2] Y. Besanger, M. Eremia, and N. Voropai, "Major grid blackouts: Analysis, classification, and prevention", in Handbook of electrical power system dynamics: Modeling, stability, and control. New Jersey: Wiley, IEEE Press, 2013, pp. 789-863.

[3] S. Smolovik, "The role of the "human factor" in the development of major systemic accidents", Elektroenergetika, vol. 1, no. 1, pp. 16-19, 2008 [in Russian].

[4] SCADA System. Application Guide., 1st ed. Milwaukee: Allen-Bradley, Rockwell Automation, 2005, p. 420.

[5] Ministry of Fuel and Energy of Ukraine. State Enterprise National Energy Company "Ukrenergo", "DS-8 instruction for the prevention and elimination of technological disruptions in the electrical part of power plants and electrical grids in the Dnieper ES region", Dnieper electric power system, Zaporizhzhya, 2008 [in Ukrainian].

[6] A. A. Bashlykov, and A. P. Eremeev, Fundamentals of designing intelligent decision support systems in nuclear power. Moscow: INFRA-M, 2017 [in Russian].

[7] A. M. Glazunova, and I. N. Kolosok, "Solving dispatch control problems for intelligent electric power systems based on state estimation methods", in Energy of Russia in the XXI century. Innovative development and management. Irkutsk, 2015, pp. 1-8 [in Russian].

[8] M. Negnevitsky, N. Tomin, D. Panasetsky, and V. Kurbatsky, "Intelligent approach for preventing large-scale emergencies in electric power systems", in IEEE Int. Conf. on Electric Power Engineering PowerTech, France, 2013, pp. 1-6.

[9] S. A. Grishanov, and N. A. Kanashevich, "Implementation of an expert system for diagnostics of generators of thermal power plants", in Collection of scientific papers of the XInt. Sci. and Tech. Conf. of Young Scientists and Specialists, Kremenchuk, 2012, pp. 305-306 [in Ukrainian].

[10] S. A. Barkalov, A. V. Dushkin, and S. A. Kolodyazhny, Introduction to system design of intelligent knowledge bases. Mos- 
cow: Goryachaya liniya-Telekom, 2017 [in Russian].

[11] A. N. Antamoshin, O. N. Bliznova, and A. A. Bol'shakov, Intelligent management systems for organizational and technical systems, 2nd ed. Moscow: Goryachaya liniya-Telekom, 2016 [in Russian].

[12] Yu. Ya. Lyubarskij, Intelligent information systems. Moscow: Nauka. Gl. red. fiz.-mat. lit., 1990 [in Russian].

[13] A. A. Azaryan, and I. A. Kotov, "Structurallogical model of facts as a means of representing the characteristics of the components of electric power systems", Hirnychyi visnyk: sci.-tech. coll. Kryvyi Rih, no. 103, pp. 136-141, 2018 [in Ukrainian].

[14] K. Iskandar， M. Jambak， R. Kosalaa， and H. Prabowo, "Current issue on knowledge management system for future research: A systematic literature review", in 2nd Int. Conf. on Computer Science and Computational Intelligence (ICCSCI) 2017, Bali, 2017, pp. 68-80.

[15] V. Morkun, and I. Kotov, "Information technologies for power supply dispatch control based on linguistic corpus ontologies", Naukovyi visnyk Natsionalnoho hirnychoho universytetu: coll. of sci. works, Dnipro: NTU "Dniprovs'ka politekhnika", no. 6 (174), pp. 130-136, 2019.

[16] S. Deveradzh, and R. Kohli, "Secrets of IT. Measuring of return on investment in information technology". Moscow: Buk-Press, 2006 [in Russian].
[17] V. Lipaev, Selection and evaluation of characteristics of software quality: Methods and standards. Moscow: Sinteg, 2001 [in Russian].

[18] B. Zhelezko, and O. Sinyavskaya, "Methods for assessing the effectiveness of intellectual components of decision support systems", Nauchnyye trudy Belorusskogo gosudarstvennogo ekonomicheskogo universiteta: coll. / V. N. Shimov et al. (ed. board). Minsk: BGEU, 2010, pp. 139-144 [in Russian].

[19] A. L. Ryzhko, N. M. Lobanova, N. A. Ryzhko, and E. O. Kuchinskaya, Economics of information systems. Moscow: Finansovyy un-t, 2014 [in Russian].

[20] Ministry of Fuel and Energy of Ukraine. State Enterprise National Energy Company "Ukrenergo", "Instruction for eliminating accidents and technological disturbances in electrical networks of VAT EK "Dniprooblenergo", Dnieper electric power system. Zaporizhzhia, 2007 [in Ukrainian].

[21] A. F. Dyakov, I. E. Lekovec, G. V. Merkurev, and A. D. Sherbakov, "Evaluation of emergency training of operating and dispatching personnel of power systems", Elektricheskiye stantsii, vol. 2, pp. 58-65, 1997 [in Russian].

[22] G. V. Merkurev, Operational dispatch control of power systems. St. Petersburg: Tsentr podgotovki kadrov energetiki, 2002 [in Russian].

V. S. Morkun, D.Tech.Sc., professor,

I. A. Kotov, Ph.D., associate professor Kryvyi Rih National University

Vitaliy Matusevych st., 11, Kryvyi Rih, 50027, Ukraine e-mail: rioexito@gmail.com

\section{CRITERIA FOR OPERATIONAL MONITORING OF PROFESSIONAL CONCEPTS BASE OF THE COMPLEX OF POWER SYSTEM CONTROL AUTOMATION}

The article is devoted to the problem of developing criteria for operational monitoring and evaluating the effectiveness of an intelligent decision support system for emergency control of power systems modes based on the use of professional concepts and specialized thesaures. Criteria for calculating the efficiency of using professional concepts of the thesaurus of knowledge on the automation of emergency response in the power system are proposed.

Scientific novelty lies in the development and application of efficiency coefficients of the thesaurus of professional vocabulary, based on the presentation of professional concepts of knowledge about 
the elimination of accidents in the power system. The obtained indicators allow us to assess the degree of professionalism and effectiveness of the linguistic corpus and build productive knowledge bases. In contrast to the existing approaches to building knowledge bases, the proposed approach makes it possible to unify the design of decision support systems and reduce the time of their implementation.

Practical significance of the results obtained is in assessing the effectiveness of using professional knowledge to build unified intelligent decision support systems in the field of emergency management of power systems. The results of the work consist in ensuring operational monitoring of the effectiveness of using the knowledge base of professional concepts of terms and slang. The model for assessing the effectiveness of a professional thesaurus, based on the ratio of growth rates of general and specialized professional thesaurus is proposed.

Research results prove that professional thesauruses are becoming more effective as they move to more specific specialized scientific and technical fields.

Keywords: dispatch control, ontology, thesaurus, colocation, semantics, abbreviation.

Стаття надійшла 15.02.2021

Прийнято 09.03.2021 